\title{
The end of the beginning
}

Citation for published version (APA):

Urquhart, J. (2004). The end of the beginning: Farewell speech by J. Urquhart. (1 ed.) Universiteit Maastricht. https://doi.org/10.26481/spe.20040101ju

Document status and date:

Published: 01/01/2004

DOI:

10.26481/spe.20040101ju

Document Version:

Accepted author manuscript (Peer reviewed / editorial board version)

\section{Please check the document version of this publication:}

- A submitted manuscript is the version of the article upon submission and before peer-review. There can be important differences between the submitted version and the official published version of record.

People interested in the research are advised to contact the author for the final version of the publication, or visit the DOI to the publisher's website.

- The final author version and the galley proof are versions of the publication after peer review.

- The final published version features the final layout of the paper including the volume, issue and page numbers.

Link to publication

\footnotetext{
General rights rights.

- You may freely distribute the URL identifying the publication in the public portal. please follow below link for the End User Agreement:

www.umlib.nl/taverne-license

Take down policy

If you believe that this document breaches copyright please contact us at:

repository@maastrichtuniversity.nl

providing details and we will investigate your claim.
}

Copyright and moral rights for the publications made accessible in the public portal are retained by the authors and/or other copyright owners and it is a condition of accessing publications that users recognise and abide by the legal requirements associated with these

- Users may download and print one copy of any publication from the public portal for the purpose of private study or research.

- You may not further distribute the material or use it for any profit-making activity or commercial gain

If the publication is distributed under the terms of Article $25 \mathrm{fa}$ of the Dutch Copyright Act, indicated by the "Taverne" license above, 
First of all, 1 am amazed and humbled by the number of people who have come great distances to participate in this event. Americans have come from 8 different states. A whole dele gation of luminaries have come from Edinburgh. Switzerland, France, Germany, and of course neighboring Belgium are represented. So it is a great honor for me to welcome all of you to Mastricht, the charm and beauty of which were factors that helped lure me here two decades ago.

The title of this lecture is taken from a comment by Winston Churchill November, 1941 , following the Battle of El Alamein. He famously described the situation as being "not yet the beginning of the end, but certainly the end of the beginning."

Using that phrase here begs that you ask: the beginning of what? The answer, of course, has to do in part with what I have done here since 1986, and in part. with how that relates to my other interests.

I have no family roots here. The main tether has been my long friendship and strong intellectual ties with Professor Harry StriuijkerBoudier. That originated a decade earlier in 1976, and it is an essential part of the present story, so 1 begin there.

Harry and I met when he was a postw doctoral fellow with the late Arthur Guyton, Professor of Physiology \& Biophysics at the University of Mississippi. I was visiting Guyton's department as part of an official asite visit for the National Institutes of Health, to which Arthur had applied for renewal of his grant support. I had been there previously for a prior renewal review. and for the first time in 1968 when I was there for a week as Visiting Professor of Physiology.

This was to be my last site visit, as I had a few years earlier resigned ny tenured professorship to become Principal Scientist and R\&D Director of ALZA Corporation in Palo Alto, California. ALZA pioneered the development of ratecontrolled drug delivery systems, and Felix Theeuwes, who spoke earlier, was one of the main sources of innovation at that quintessentially innovative firm that Alex Zaffaroni had founded in 1968, and which Felix and 1 joined at about the same time in 1970 .

My defection to industry put me into the category for which Walter Nimmo and I have coined the term adefrocked professors. My days as a consultant to the research grants side of NIH were thus numbered, though I later served a 3-year term on the NIH Director's Advisory Committee in the latter 80 's. But, back to nuy first meeting with Harry Struijker-Boudier.

As site visitors, our fol was to review the scientific quality of Guyton's research program, which had a staff of about 70 people. During our visit, a lunch was organized that brought the site visitors together with the entire faculty and staff of Guyton's group. By chance, I was seated opposite Harry, who, at that tine, was a freshly minted PhD in phamacology doing postdoctoral research in cardiovascular physiology and systems analysis. I was stunned by this highly unusual combination of pre- and postdoctoral work. Most pharmacologists shun both physiology and even the simplest concepts in 
systems analysis. Harry was - and 3 decades later still is - a lone but now internationally recognized leader in integrating phamacology and systems pliysiology. The fact that we are here today is a direct consequence of that chance meeting in 1976. Given the numbers of people at the lunch, there was about a $1.5 \%$ chance that we should have ended up sitting close enough to carry on a serious conversation.

We sure-wistors strongly endorsed Guyton's program, and Harty and 1 kept in touch. About a year later I phoned Harry about the possibility of running some computei simulations of the actions of a group of polymers of hemoglobin that my ALZA colleague, Pieter Bonsen Calso Dutch), had made. We had the idea that substituting the hemoglobin polymer for red blood cells could reduce the viscosity of blood, and thus reduce the work load of a damaged heart, giving it a better chance to recover. Guyton's computer model of the mammalian cardiovascular system was appealing, because he thad been steadily developing it for 25 years, By 1976 it embodied the findings of hundreds of published cardiovascular research studies, and thus had most of the interactivity and self-regulatory properties of the actual systen. It was anique resource, and an ideal way to study the therapeutic usefulness of Pieter Bonsen's hemoglobin polymers.

Harry agreed to collaborate, so Bonsen and thew to Jackson. We had precise physical and chemical data on the hemoglobin polymers, and Hany knew how to adapt the model to imcorponate the new properties of blood created by substituting varying amounts of the polymer for red blood cells, Wo then ran many simula tions with different degrees of cardiac damage to see if the substitution of polymer for red cells made any difference in the subsequent course of cardiovascular events. The simulations ran in accelerated time, so that we were quickly able to examine dozens of scenarios. Within about 4 hours we had the answer: there was no benefit from substituting any of the family of polymers we had for red blood cells.

\section{THE WHOLE IS GREATER THAN THE SUM OF ITS PARTS: EMERGWNT MUNCTIONAL PROPERTIES OF HIERARCHF- CAL SYSTEMS}

The reason was a classic illustration of how differently whole systems can behave, compared to their individual component parts. At ALZA, we had been thinking only of how the heart would respond to lowering the viscosity of the blood it pumped. What we had not foreseen was that low-wiscosity blood flows with unusual ease through the blood vessels, resulting in a big increase in total flow running off from the arterial to the venous side of the vascular tree, then returning to the heart, which it, in turn had to pump. So the potential benefits of lessening the work of the heart, by lowering blood viscosiry, were offset by a big increase in the volume of blood the heant had to pump.

As we were shutting down the computer, Arthur Guyton came in and asked us how our work had gone. I told him that we had gotten a very clear answer to our question. He asked me to tell him again what our question was. I told him about the idea of lessening the work of the heart by reducing blood viscosity. 
He then sank into deep thought for what must have been at least 3 minutes - a long time when people are just standing around looking at each other. Finally, he said: "It won't work; and proceeded to tell us what we'd learned from the simulations. He had run the simulations in his head; based on his 25 years of experience in building and refining the model. It was a good reality check on our simulations. It was also a vivid demonstration of the power of human thought, disciplined by experience in both qualitative and quantitative analysis.

In the succeeding 28 years, events have only strengthened the conclusions we reached during this remarkable half-day of work in Jackson, back in 1976. We spared ALZA from entering into what would been an ultimately fruitless but costly endeavor in product development. Others have tried things similar since, with big losses and no success.

\section{HISTORICAL ASIDE: THE INDUSTRLAL INCUBATOR ROLE OF ALZA CORPORATION}

I believe that this was the first application of modeling \& simulation in pharmaceutical product development. Others started using modeling \& simulation duting the last decade. I have suggested that Harry, Pleter Bonsen, and I Jointly have revenacted the roles of Prince Henry the Navigator; Vasco da Gama, and Vasco's first officer in respect to modeling and simulation in dng development.

This story is just one of many examples of ALZA'S remarkable history of innovations that were highly effective for the tasks at hand, but have had little or no recognition within the pharmaceutical sciences. Certainly we never shy about promoting ALZA technology and products, but we put the emphasis almost entirely on the main theme, which was improving the therapeutic value of drugs by delvering them continuously at controlled rates, rather than intermittenty in slugs. Some of the unsung but important 'firsts' at ALZA were, besides the first use of computer modeling and simulation in drug development and decision-making, development of the first electronically monitored drug package to compile dosing histories in ambulatory patients, the first radiation-sterilized human phamacentical product, the first pharmaceutical product to have its strength specified by its rate of drug relcase in vivo, rather than by the amount of drug it contains, and the rewriting of the pharmacologies of scopolamine, pilocarpine, and nifedipine.

As for modeling \& simulation, I had already made heavy academic use of this approach during the latter 1.960's (1) in my earlier career as Professor of Physiology in the Department of the late Ernst Knolbil at the Uniw versity of Pittsburgh. Ernie Knobil is present in spirit here today.

The story of the hemoglobin polymer not only describes my first link to Harry struijkerBoudier, but also highlights ny most basic intellectual interest. "That is why I labor a bit over it, for it is the wellspring of all my subsequent interests - drug delivery systems, patient compliance. pharmaco-epidemiology, and physiological systems anatysis. To give this wellspring a name, I would suggest: the emergent properties of contiplex systemins. 


\section{ON EMEROENT PROPERTES}

The tem 'emergent' means that, when you put several components together in a work ing system, the system acquires functional properties not seen in the indlividual components operating in isolation. Novel properties emerge from the interactions of the component parts.

It points to a very basic problem in biomedical research, embodied in the present exuberance about the human genome. We now have the thuman genome defined - a phenomenal accomplishment, considering that the basic genetic code was discovered only 50 years ago. But having gotten the map of the human genome, with due accolades to those who worked it out, where do we now stand? Naturally we are better-informed, but the quest to cure cancer has not suddenly ended. Frar from it, for recently we were informed that it is going to take maybe 25 years to understand how to interpret the genome. That prediction has to be seen in light of the fact that 7 years is about the limit of credibility in the predlictions business. " 25 years" is tantamount to saying *longer than l'll be around to be accountable for the prediction.

So, all those clams for all those years that getting down to the molecular level would solve the big problems in medicine and biology have turned out to be the 'hype' of a faulty epistemology - not an automatic solution to the big problems, but just another step along the way.

The genome is a component at the botfom end of hierarchical organization of biology. As Table 1 shows, one can readily identify 11 discernibly distinct levels of organization, each with its own functional characteristics that emerge from its components.

\section{TABLE}

\section{LEVEL CONSTTTUENTS}

1 Populations

2 Closely intercommunicating groups of organisms (herds, fledlots, villages, tribes, watersheds, salles territories, special interest groups, etc.)

3 Mother \& fous(es)

4. Whole ongahsins (nature or immature males, temales)

5. Orgun systens (heart, lungs, kidneys, adrentids in congestiwe heart failure; CNS, heart, lungs, muscles in exencise, etc)

6 Organs (brain, hear, muscles, liwer, kidney, endocrine glands, etc)

7 Groujs of directly intercommunicating cells (the nephron, the hypothalanic-pituitary axis, adrenal medulla being downstrean from the adrenal cortex, etc)

8 Cells

9 Subcellular structures (microsones, mitochondria, the nucleus, etc)

10 Croups of intericting molecules (Uhe genome, enzyme systems, drug receptos \& internal signalling mechanisms, etc)

11 Molecules (genes, encymas, drug receptors, etc) 
One could use different tems, or different approaches to categorization of these different levels of biological organization, but the essential point is that each of these levels of organization manifests emergent properties.

These 11 different levels have academic disciplinary echoes, starting with biochemistiry and medicinal chemistry at levels $11 \& 10$, virol ogy at level 10 , cell biology at 9 and 8 , physiology and classical pharmacology an 7 through 3 , epidemiology at 2 and 1 . Note that the upper levels are not much in academic vogue in recent years. That will have to change, as the task for the next half-century is the understanding of those emergent properties, how they arise from and link back to mechanisms at the lower levels in the hierarchy.

To anticipate a key conclusion pertinent to pharmacomepidemiology, one can see that classical pharmacologists work at levels 3-7. molecular pharmacologists work at 10 and 11 , and pharmaco-epidemiologists work at levels 2 and 1 . At level 2, for example, an especially persuasive sales rep can have a major influence within his or her sales territory on how a drug is used and the prevalling health status of the patients who are prescribed the drug in question.

Of course one of the reasons for rapid advances in the discovery of, e.g., antiretroviral drugs for treatment of HIV infections, is the fact that the retroviruses are organisms that basically represent level 10. Mechanisms operating on groups of molecules are not subject to modification or nullification by emergent properties at levels higher than 10 . At the same time, how- ever, the nore successful drugs are those that have not single but mutiple meclianisms of action. Antiretroviral drugs, like systemically administered drugs of any class, have to be absorbed, distributed, and metabolized, and so they pass through levels 5-9 before geting, in some form or other, and at some concentration or other, to the retrowinuses which they ane designed to attack.

The development of drug reststance is a najor problem in all areas of infectious disense treatment, and that process depends on mutitions. Resistance is readily achieved of only one mutation is required, but slowly acheved if it takes a half dozen or more mulations. But even viruses are influenced by the buman biological hierarchy, for the whole topic of emergent drug resistance is dominated by level 4 , where patients: negligent closing patterns an allow drug levels in blood to fall to a critical range low enough to permit viral replication, but high enough to exert selection pressure favoring the replication of drug resistant mutations.

Let us now turn to the specifics of why I came here, and what has been accomplished in the intervening 18 years.

\section{HOW I CAME TO COALI HRK}

One day in 1982, the late Errogt Barany and I were at a terribly boring meeting in Gothenburg. We slipped awy and took a long walk. Enst was a member of AlZA's Scientific Advisory Board, Professor of Phamacology at the University of Uppsala, Sweden, and had the professortal 
chat of Carl Linnaeus, who had, in poetic terms, "named the flowers", and, in biological tems, had created the taxonomy of botanicals. Hrnst also here in spirit. Durith ow walk, he and $\mathbb{1}$ dis cussed the lack of good drugs for treating congestive heart fallue, which, during the $20^{\text {th }}$ cenwry replaced infectious diseases in the western countries as the man pathway to the grave.

Ernst made the suggestion that ALZA sponsor a systematic exploration of how the awallable drugs for the failing heart might be used in combinations. Most cardiotonic drugs have very narrow margins between effectwe and toxic doses. One would look for combinations where two atrugs' levels of effectiveness were additive, but where the side-effects differed and were not additive. It was an excellent idea, wellsuited to ALZAS capabilities and needs, and capable of meeting a major unmet medical need. But it called for very carefull work in thoroughly understood animal models. I immediately thought of Harry and his colleague, Jos Smits, who had already demonstrated their mastery of careful, quantitative analysis of cardiovascular drug actions in well-understood animal models. Harry and Jos liked the idea, and, in due course, they decided to undertake the work, but they said that they would like ne to come over for severil months to work with then th the progrem got underway. I convinced my ALZA colleagues that this wats a good thing to do, and so went off on what amounted to a self-created sabbatical during the summer of 1984 .

During the previous year, I had enclured a grueling controversy about an ALZA product on which high hopes had rested: the oral osmotic pump form of the widely-used but sideeffects prone anti-inflammatory drug, indomethacin. The new osmotic pump formulation had been jointly developed by ALZA and Merck, Sharp \& Dohme, and was launched under the rademark, OSMOSIN, in the UK, Germany, and 5 other countries in the spring of 1983. Many patients found it a substantially better product than conventionally formulated indomethacin, and that clinical impression quickly turned the product into the most successful new product in the history of the UK pharmaceuticals market. But by mid-summer, adverse reaction reports were beginning to come in at a brisk rate, and by August there began a media frenzy in the German press, based on news leaking out of the British drug regulatory authority. The British press more or less goes on holiday in August, but when they returned in early September, they, too joined the frenzy, and by the end of the month the product was forced off the market.

As these events were coming to a crisis, I put together a program with Bill Inman, to analyze the British reports of adverse drug reactions, and to use Bill's prescription event monitoring system to understand as well as we could what had gone wrong. Bill had coined the term pharmaco-epidemiology, and was the world's first professor of the discipline at the University of Southampton. The responsible people at Merck, Sharp \& Dohme appeared to want nothing other than to put this bad experience behind them as rapidy as possible and move on to other things. The burning question for ALZA was whether this was inherently a drug problem or a delivery system problem, a question that was beginning to 
enter public debate. It was certainly known at a qualitative level that indomethacin had created utcers in every segment of the gut, from the esophagus to the rectum. Since the introduction of indomethacin in conventional capsule form a decade earlier, however, new methods for gathering information on adverse drug reactions hat come onstream generating quantitative data on OSMOSIN, but only qualitative data on indomethacin in capsule form. That one-sided comparison created the illusion that the new, osmotic pump form of indomethacin product was much more hazardous than the old, capsule form of the drug.

Our aim at ALZA was to understand those matters fully. By the time I came over to Maastricht in the summer of 1984 , there was already clear evidence that many prescribers had responded to news about the favorable sideeffects profite of OSMOSIN, and had opted to prescribe the product to patients with an unusually high background incidence of peptic ulcer disease. It was also clear that there were substantial errors in the database on which the decision to withdraw the drug had been taken, including some patients who had never gotten OSMOSN in the first place, and others who were double-counted because of derical arrors. I was brooding over these problems, how to measure them, and how to prevent them, while working with لos Smits on heart fallure models.

Also, during the summer of 1984, Joan and I did a lot of bicycling in the area around Maastricht, which served to fix the geography in my head. I formed the idea that South Limburg, surrounded by Belgium and Germany, with its major medical center in Mastisticht, could be a good region in which to establish a research program in phamaco-epidemiology. So, I wote a letter to Dean Co Greep, also here today in spirit, suggesting that the University could neet a malor unmet need in post marketing survellance of prescription drugs if it could mount a program in its surrounding region that could insure reliable ascertainment of drug exposure. That leter triggered the formation of a study-team, which included the then-Professor of Epidemiology, Ferd Sturmans, Harry, and the then-Secretary to the University, Edward Steur.

Meanwhile, back at ALZA, my selfcreated, one-off sabbatical had triggered bureaw cratic reactions, one of which was the creation of a sabbatical program within the company. I could see that bureaucratic sclerosis was making headway at ALZA when I was notifed officially that because of my 14 years of service, I was awarded a 3 month sabbatical. So, I took the system at its word and spent a second summer in Mastricht, in 1985. I was also by then working on the founding of a new company, APREX Cotporation, to develop electronically monitored pharmaceutical packages that could measure patients' compliance with prescribed drug dosing regimens by compiling ambulatory patepts" dos" ing histories.

Meanwhile the heart fallute work was progressing nicely under Jos Smits's direction, and, without going into detyils, I would just say that that by the time the anmal model worts was well-enough along to begin studying the interactions of cardiotonic drugs, I had lett ALZA and the work here began to veer in other, equally 
interesting directions which have been tremendously productive, including many publications and Jos Smits's later receipt of an Established Irvestigatorship from the Dutch Heart Fund in 1986, and the Organon Award of the Dutch Pharmacological soclety in 1990 . The original suggestion of Ernst Barany still awaits study. I'm thinking that 1 might apply for a post-doctoral fellowship in the Department of Pharmacology to pursue that original question.

Jos Smits noted, in checking the dates of his various awards, the following note: at think that also the 11 million Euro grant that I recently got for 'molecular imaging of myocardial ischemia' can, to a large extent be considered as a spin off of the things you initiated in 1984".

During 1985, several key things happened. The idea of starting research in pharmaco-epidemiology in Mastricht was supported by all involved. The Dutch government had informed the pharmacists that they would pay For drugs within 3 days on electronic data, versus 10 days on paper data. That administrative change created the key economic stimulus to computerization of pharmacies.

Then it gradually dawned on me that the real opportunity here lay, not in the special geography of south Limburg, but in the fact that community pharmacies were now computerized, and that the Sickfunds' long requirement for insured patients to designate a single phamacy for all rembursed prescriptions created an unique opportunity to have essentially complete, reliable, objective data on large numbers of ambulatory patients' exposure to prescription drugs. We devised strict controls to protect patients" privacy. We could work with drug dispensing records that showed the patient's age and gender, which was good enough to minimize confusion of two patients and robust enough to protect patient privacy. Moreover, the study of drigs actually dispensed bypasses one of the gaps in ambulatory care, created when prescriptions are written but never taken to the pharmacy for dispensing. Those prescriptions create no exposure to drug. and are not counted because our method counts prescriptions dispensed.

As occasionally happens in epiclemiology, administrative mechanisms create unique opportunitics for epidemiological research. Here the Sickfunds requirement for a patient-designated single pharmacy assured wirtual completeness of records, and the change in payment times introduced the computer into community pharmacies all over the country making it practical to gather and analyze large numbers of patients" drug dispensing histories. It is a good illustration of Pasteur's dictum that "in research, chance favors the prepared mind.

One further and very important aspect of the work was the recognition that a prescription drug history is in fact a kind of cameo medical history, because of the relatively specific medical indications for use of almost all modern prescription drugs. I frankly don't know whether I was the first person to grasp that point but certainly my prior 15 years of work in the pharmaceutical industry made me quite aware of the fact that what it says in the labeling focuses how drugs are marketed and used. So regardless of the originality of the concept that a dispensing history can 
be read as cameo medical history, it has been a fundamental in all the work done here since its inceptions in 1986. It is a very important point, for pharmacy data are uniformly fomatted and must contain essential features for them to be the basis for reimbursement. Thus, they have the qualiry of financially auditable records.

1 had no interest in poking around in physicians' records, which are often haphazardly formatted, and sometimes vague in respect to prescribing information. There are, to be sure, occasional instances in which interpretation of drug dispensing data requires some extra information from the prescriber. These have been infrequent, but we devised a way to discuss individual patients with the prescriber without breaching patient privacy. We inform the pharmacist which record we need to discuss, and the pharmacist in turn informs the prescriber which patient it was we wanted to inquire about. Thus, patient privacy is preserved.

So we had in outline the basis for a sys. tem that could be expanded to include multiple community pharmacies, which assured strict maintenance of patient privacy, which provided solid eviclence for drug exposure, and which, most impontanty, allowed us lo look buck at what drugs the patient had been prescribed before the appearance of a new drug in the market. Thus we could assess channeling, which, until our work, had been only a theoretical construct.

The late Alvan Feinstein, who is also here in spirit, and his colleague Joseph Concato, had faced a similar problem of charactenzing the comparative severities of comorbid condi. tions among grotips of patients (2). They attacked it by brute force - creating a commitree of three experienced internists to do a detalled review of the medical records of large numbers of patients. They did this as a one off procedure to resolve a question about differences in the longeterm afrer-efrects of the wo main types of prostate surgery. They were they able to eliminate the susplcion that there was a afference in long-tem after-effects of the two types of sugery. The proper explanation was selection bias, created by the fact that the one type of suggery tended to be used in parients who were sicker than those who got the other type of surgery. Naturally, the originally sicker patiens fared loss well in the long rum than did the healthier ones. Such intensity of review presumed, of course, good data in medical records - possible for con ditions that had patients in hospital, but not possible in ambulatory care.

The initial pilot work here (3) was done by Hans Petri, with the collaboration of Rieki de Vet and Fons Kessels, using, to start with, the dispensing data in the computer of Jack Naus at the Apotheek Nederweent. Nederweent is a lovely village about an hour's drive north of Mastricht. Jack Naus has been an unstintingly enthuslastic collaborator and confident ptoneet in the work done in Mastricht; his willingness to make anonymized data avallable for phamaco-cpi demiological analysis crewed the conerstone of the work. Hans petri has been an invaluable coworker throughout the formative stages of this work, and his thesis on the prescription drug history and what can be done with if, is a comerstone of pharmaco-epidemiologic reseata on ambulatory patients (4). Hans also has good 
organzatonal skills, and played a leading role in creating the stichting Parmacoepidemiologie, which allowed creation the chair in pharmacoepidemiology at Masstricht that I have held sinee 1991. Hans was my second graduate student, and his thesis (4) is an excellent record of the unfolding of phamacoepidemologieal reseach here. My very first studen, Richard Bergman, is; by remarkable eoincidence, being honoted this very day by the American Diabetes Association with a special dirner in Los Angeles. Richard is Professor and Chaiman of Physiology at the University of Southern Callforma Shool of Medicine, and is a recipient of the Lilly Award from the American Diabetes Association (5) and other honors. He did his graduate studies in physiology under my direction at Pitsburgh, finishing in 1970.

Jack Natus has ably and enthusiastically served as the Stichting's treasurer, which has been real work. Jack and I found novel ways to keep the stichting financed, which was easiest when an affuent pharmaceutical industry was paying front-of-plane air fares, and I was willing to fly in the back of the plane, with the huge differences nurturing the Stichting. Lately, the pressures on the industry have made that maneuver much more difficult, so my successor will have to find other ways to keep the stiching healthy.

This chati is the first in the Netherlands, and the second worldwide. Since Bill dnman"s retirement at southampton, I have described myselt the world's oldest, longest-serving, and largest professor of phamaco-epidemiology. Having triumphed over the dreaded curse of anorexia, I am virually assured that my successors will be strmaller people than I.
There was never any question of my doing this work on full-time basis, for I had too many other things going on to allow this activity to be more than a fractional one. The same year I started coming here, it co-founded APREX Corporation in Palo Alto, California. That company's mission was to develop electronic methods for compiling drug dosing histortes in ambulatory patients, using timekeeping and time-stamping microcircuitry integrated into pharmaceutical packages. This method - formally called electronic medication event montoning - provides data complementary to what we were starting to gather from Dutch communty pharmacies. Electronic monitoring provides the micro-ascentainment of drug exposure, hour by hour, day by day, week by week. The prescription dispensing records we studied here in the Netherlands are a semi-micro ascertainment of drug exposure, for they do not show the hour by hour or day by day detail, only when a prescription was dispensed, what the prescription called for in the way of drug, dose, dosing frequency, and quantity of drug dispensed - which created a de facto definition of the duration of dosing under the prescription. Of course it depended on how regular the patient was in taking the medicine. If the prescription called for once-datly dosing of a single tablet, and 60 tablets were dispensed, you could expect that patients who dosed regularly and punctually would take the last of the 60 tablets precisely 60 days after the first dose. In contrast, if the patient skipped half of the scheduled doses, then it would take 120 days to finally come to the last tablet. We wrestled with such uncertainties inherent in dispensing data, but it was dear from the outset that we had in hand a system that was a quantum jump in the relability of ascertaining ambulatory patients exposure to prescription drugs. 
Today , there is increasing integration of the dispensing history data with electronic dosing history capture, and, in some instances hospital admission and discharge diagnoses, and laboratory test results. Such capabilities were only a distant vision in 1986. They have been catalyzed by the insightul thesis research of Erik de Klerk (6), whom I count as my second graduate student here, though officially he was categorized as a student in rheumatology.

You will note that I have had only 3 graduate students - Bergman, Petri, and de Klerk. My real interest is not in teaching students to become analysts, which is the orientation of the PhD thesis, but rather to teach people how to integrate. Skilled integrators in today's world become Chtef $\mathbb{E x e c u t i v e ~ O f f i c e r s ~}$ or Chairmen of their respective firms. I count 14 people who have worked for me, and who have gone on to be CEO's or chairmen. I believe strongly that a major challenge to academia is to reorient graduate study towards integration and integrative systems analysis, from which will come the minds that will solve such problems as how to understand the functionality of the human genome, how to predict emergent characteristics of complex hierarchical systems, how best to manage large organizatons, and the like.

Very soon after getting started, Hans Petri and I were joined in our work by Bert Leufkens, who was then still a graduate student at Utrecht, originally interested in what was called 'social pharmacy'. Bert and his mentor, Albert Bakker, Professor of Community Pharmacy at Utrecht, quickly realized that epidemio- logical analysis of prescription drug dispensing data was to become an important component of the pharmaceutical sciences. More about Bert later.

This basic approach, for which Jack Naus's pharmacy was the pilot, has stood the test of time and increasing numbers. Today, stating from our pilot work with Jack and his half-dozen physician colleagues in Nederweert, the approach was adopred and greatly expanded by Bert Leulkens and his colleagues at the School of Phamacy in Utrecht, and has been recently extended, wnder the direction of Ron Herings, into a commerchal venture, the PHARMO Institute of Drug Outcome Research. I wew commercial ization of the pharmaco-epidemiologic approaches we pioneered here as the ultimate ratification of their value. PHARMO has acoess to dispensing reconds in the computers of Dutch phamacies serving in excess of 4 million patients.

Many take a negative view of conmercialization of what has started as an academic program, but when success of the academic program begins to attain a certain size, it is time to spin the activity out into the marketplace and not try to run a de facto commercial activity from inside the University, My views on this were orignally informed wher I came als a junior faculry member to the University of Pittsburgh School of Medicine mme diately after Jonas Salk had departed to La Jolla, Califoma. Salk had run a commercial-scale vac cine development and production enterprise inside the University. "That big enterptise vianed many academic careers, for it is not in the nature of industrial-scale activities to provide publishing 
opportunities. The spin-out of PHARMO from the Department of Phamaco-epidemiology and Therapeutics at Utrecht has come at precisely the right point in the scalc-op of community phamacybased ascertaintient of drug exposure.

On the academic side, there are now thee professoral chairs in pharmaco-epidemiology, where there were none when I started here in 1986. The Netherlands has more professors of phamaco-epidemiology on a perwcapita basis than any other country in the world, and what is called the burch School of Pharmacoepidemiology is a leading part of the International Society of Pharmaco-epidemiology, of which Bert Leufkens is past-president.

Bert Leufkens has brought uniquely effective leadership to pharmacomepidemiology not only at Utrecht, but nationally and internathonally. His predecessor, Albert Bakker, had the great foresight to recognize both the growing importance of pharmaco-epidemiology and the unique contribution that this country can make to the discipline. As Albert was retiring; he organized the transition of what had been a Department of Community Phamacy to a Department of Pharmacowepidemiology \& Therapeatlcs, wilh Bert Leulkens as its first Chairman. Albert also promoted me for a honorary degree from Utrech in 1997, which was a splendid way to help promore phamaco-epidemiology.

Bert Leufkens brings unique skills in analysis, organization, and management to the full ronge of challenges that beset the Brofesson and Chairman of a large department. We have had many adventures together over the past 18 years. Just a year ago, Ben and I took a week of his wellearned sabbatical to drve across the U.S., in a rented Cadillac, from San Francisco to the East Coast, with intermediate stops in Death Valley, Bryce Canyon, an unseasonal heavy snow in the Rockies, antiques in Kansas, the architectural gem of Columbus, Indiana, Abraham Lincoln's log cabin birthplace, a Shaker Village in eastern Kentucky, and the monumental art collection of the Barnes Foundation in Philadelphia. In addition to all the scenic splendors, we had the opportunity for many discussions. I brought along my radar detector, so we also refined the art of early detection of police radar signals, which greatly facillitated our forward motion. (Radar detectors are legal in most American states.) Each day's twilight was mellowed by moderate portions of Lagavulin, one of the finest of the single-malt scotch whiskies.

\section{ON CHANNELNG}

The most important finding to come out of the pharmacoepidemiologic work in Mastricht has been the discovery of the phenomenon we call 'channeling' (7). It describes an important effect of market positioning on the composition of the groups of patients who are pre. scribed the product. The concept is at once both simple and subtle. Imagine a new pharmaceutical product that is the $4^{\text {th }}$ entry in its field. So already there are 3 other like-indicated products competing for share in the market. The new product's management faces the challenge of creating for the new product some distinguishing feature that would cause physicians to prescribe it. "Stronger" is one possibility; "fewer side effects" 
or "better tolerated are others. "Longer lasting" - maybe. Or an additional pharmacological feature - e.g., let us say that the new product happens to have the property, besides its main indication, of preventing seizures, or lowering $L D L$. cholesterol. If there is something in the promotional program that moves physicians to prescribe the new product relatively selectively for patients who have unusual co-morbidity or unusually severity of the disease which is the primary indication for prescribing, then the resulting group of users of the new product will bring those atributes and their sequellae into the postmarketing surveillance data on the new product.

Hans Petri discovered a particularly strong example of channeling in asthma pattents prescribed one of the three then-available types of inhaled beta-2 agonists - salbutamol, terbutilene, or fenoterol. In asthma, a key indicator of disease severity is the prescribing of systemically administered steroids. Hans found that a much higher proportion of patients prescribed fenoterol were coincidentally receiving systemic steroids than either of the other two agents. "The marketing program for fenoterol was centered around two features: (a) an implicit claim that fenoterol was inherently more powerful than either of the other two beta-agonists; (b) promo tion focussed on pulmonologists rather than on general practitioners. Some combination of these two factors, and perhaps others, was responsible for fenoterol's channeling into patients with more severe asthma (8). The upshot of the channeling, however, is that, ceteris paribus, the occurrence of adverse events, and the flow of reports about them, will be higher in recipients of fenoterol than in recipients of the other two agents.
Note that this is an emergent property of this class of drugs. The several drugs in the class went into patients with quite different co-norbidities. Yet if studied in carefully controlled tials they are not distingushably different Clincal pharmacologists study the actions of the drugs in controlled trials designed so that the drugs are tested in comparable patients. That is the root reason for randomized assignment of trial participants to each test agent, to assure that observed differences can be attributed to differences in treatment agents, and not subtle differences in the patients recelving the different agents. But at the higher level of organization, where real patients are prescribed the agents for pre: vailing reasons, fenoterol acquires the emergent property of having a flow of adverse reaction reports driven by the peculiarities of the patients to whom it is being prescribed. Fature to grasp this important emergent property of the drug in its everyday use led to its withdrawal in some countries, and to suspicions about its relative safety that have curtailed its use elsewhere.

Hans Perti, Bert Leufkens, I and others found the same sort of thing happening with a delivery systems form of a nonsteroidal antiinflammatory drug called ketoprofen, introduced into the Dutch market by smithkline. The pro. motional program for the smithkine product looked like a photocopy of the eartier MSD mar. keting plan for OSMOSIN, emphasizing the advanced technology of the ding delivery system and how it can mitigate the usual gastro-intestimal side-effects of the drug. We could now do for the SmithKline product what no one was able to do (on even thought about) for OSMOSIN. We used the patients' prior receipt of prescriptions 
for cimetidine, ranitidine, and other inhibitors of gastric acid secretion, used for dyspepsia and peptic ulcer disease, as mankers for prior history of these conditions: the delivery system form of ketoprofen indeed had a uniquely high prior use of acilinhibiting drugs compared to other antinflammatory agents being introduced at the time into the markeplace. We also saw an unusually heavy fow of adwertse reaction reports, but the knowledge of ts channeling into problempatents convinced the Dutch regulators not to withdraw the product, thes sparing it from the earlice fate of OSMOSIN (9)

\section{THE UR-PRONLEM IN PHARLACO-EPDDRMOIOGY}

It illustrates what I have termed the urproblem in pharmacoepidemiology: did the product bring the problems to the patients, or did the patients bring the problem to the product? twould say, as a kind of rule of thumb, that the latter seems to be about twice as likely as the former.

\section{SLCOND-GUESSING PRESCRIBERS?}

This work naturally put me in a position to second guess the prescriber and, had I wished. 10, I could have gone off into an attack on the quality of prescribing. I wasn't here very many days before deciding that the quality of medical prictice and prescribing was a place I would not go. Physicians win and do make mistakes, but nity aim was to develop methods that could cast light on the actions - beneficial and harmful - of presctption drugs in large groups of patients exposed to them. Fortunately, I was never confronted with the ethical challenge of discovering evidence of gross malpractice that would have forced me to abandon my policy of acting on the assumption that each GP in our database was a well-informed, medically skilled, hard-working individual, consistently acting in his/her patients' best interests.

\section{THE LATEST THING}

Several years ago, Bert and I attended a meeting of the European Drug Utilization Research Group ar the Dead Sea. We met with the people who run the WHO Statistical Research Centre in Oslo, and who have the task of defining so-called 'defined daily doses' (DDD's) of each of the major prescription drugs. In a moment of inspiration, we asked the head of the Centre if she would post on their website all the changes in DDD's since they first started to compile them, which was about 1980. So, in a few weeks, the list of changes in DDD's appeared on their website. With Rob Heerdink, Bert and I analyzed these changes, and examined the time-trends. In summary, we found different trends among antinfective agents and all other classes of drugs. The former showed mostly increases in DDD, whereas the others showed mostly decreases. And, among the non-infectous disease products, the time trend of products undergoing DDD decreases showed a striking rise since 1990. Mcanwhile, Carl Peck, who spoke earlier, and his group at Georgetown, had been studying the same phenomenon, but based on FDA-approved changes in labeled dosing recommendations. After some discussion, we agreed to put the two 
papers back to back in the phamaco-epidemiology society's joumal, Pharmaco-epidemiology \& Drug Safety. The editor, Ron Mann, agreed with our suggestion to accompany the two papers with an editorial, which Harry Strujker-Boudier was invited to write. The whole package appeared in the September 2002 issue of the journal (10-12), and, with a bit of deft PR on our part, got wide attention in the news media, including the New York Times and the NRC Handelsblad.

\section{AND SO,}

That was it ... that was why I chose to spend $20 \%$ my time coming to this

sometimes coild, often dark, sometimes beautifully springlike or summery city for periods of a week or two, at intervals of 1-2 months, cast into jet lag for a third to half the time I was here. I cannot tell you how many times I set out in the morning of my $2^{\text {nd }}$ or $3^{\text {rd }}$ day here with a profound sense of fatigue, wondering to myself "why do I do this?" Flying from California forced my biological clock to

grind its gears over the 9-hour time difference. I have had some memorable afternoon naps, but many periods where my best work was done between 2 and 6 in the morning.

Occasionally I stayed for longer periods, but those were an exception. Most of my comings and goings had the attribute of the Cheshire Cat in Alice in Wonderland - now you see me, now you don't. Fortunatelly, the advent of lowcost transatlantic phone calls, and of the internet made it possible to communicate as well, if not beter, than were I here on a permanent basis.

\section{IN SULAMAWY}

In summary, in the past 18 years, elght main things have been accomplished in phatmaco-pidemiology in this country:

FIRST, the creation of practical, low-cost, privacy-assured, methods for using Dutch community pharmacy dispensing records to ascertain ambulatory patients exposure to prescription drugs.

SECOND, demonstration of the virtual sufficiency of dispensing data, as a cameo medical history. for sound phamaco-epideniological interpretation.

THIRD, creation of a privacy-assured way to supplement, when necessary, dispensing data with information from prescribers.

FOURTH, first demonstration of the utility of studying prescribing sequences, known as prescription sequence analysis (or to mandarins as the case-crossover method).

FIFTH, discovery of a practical way to identify and semi-quantify the existence and importance of the channeling phenomenom.

SIXTH, demonstration of the rising number of newly registered prescription drugh that enter the matket with recommended doses that are set too high.

SEVENTH, the establishment of phamacomepidemiology as a robust academic discipline in the Netherlands. 
EIGHTH, the transition from pilot scalle to research scale to commercial seale of the use of communiry pharmacy dispensing records as the centerpiece of Dutch pharmaco-epidemiology.

My role in all of this has been mostly catalytic, and, of course as the work gets more and more into a roune application of established techniques, the need for catalysts properly diminishes, so this is a good time to stop.

\section{UNFINISHED BUSINESS}

Some intortant unfinished business is:

First, to define methods for ascertaining the sufficiency of channeling as an explanation for adverse events

Second, to demonstrate and quantify the consequences of the holiday pattern of drug dosing hazardous rebound \& recurrent first-dose effects in cardiovascullar and other drug classes, emergent of drug resistance among anti-infective agents.

Third, to put in place ongoing, routine surveillance of new pharmaceuticals entering the Dutch market.

Pourti, to understand betier the forces that ate driving the increase in overestimated dosing requirements.

\section{WHAT'S NAXT?}

My main interest has been and remains defining the clinical explanatory power of drug exposure data at the micro level of daily dosing patterns, captured by electronic monitoring. That work has been greatly facilitated by the work of Bernard Vrijens and his colleagues at the AARDEX Statistical Research Centre in neighboring Visé, Belgium. My close working relation with Bernard and his colleagues means that Joan and I will keep our apartment in Maastricht and continue to use it both because of its proximity to Vise and as a way-station for other things that bring us to Europe. It also means that I can continue to be a regular at my neighborhood café, 'tPrusske, at 9 Hoogbrugstrat, where my caricature is $3^{\text {rd }}$ from the left on the wall opposite the door, for about 10 years since the tiprusske regulars were sketched by a passing caricaturist. Ed Niesten, the proprietor, is in the audience today. My original café was the Old Clock in the Tongerseweg, but the clientele changed over the years, and eventually George Hoebrechts, its proprietor, retired: George and his wife Fien are here today. I hope to lake retirement lessons from George, who seems to have mastered the art.

I serve on 3 Boards of Directors, 2 of them publicly traded companies. I am Vicechairman of Inveresk Research Group, the remarkably successful firm brillandy led by another defrocked professor, Walter Nimmo, who is here today, leading the group of luminaries from Edinburgh. It once was easy to be a board member, but recent events have made it far more demanding, for I have to chair the corporate governance committee, and endure the agonies of service on the audit committee. I'm also a Board member of a California firm called Biomarin Pharmaceutical Co, which focuses on 
replacement enzyme therapy for children with enzyme deficiencies created by inborn errors of metabolism.

I also serve on one of the boards of HBM Bioventures, which is a very dynamic Swiss-based, privately-held venture capital firm. Its founder, Henri B. Meier, created the firm as he retired from his legendary years as $\mathrm{CFO}$ of Roche. I sometimes think of Henri as a sont of Swiss enantiomorph of America's Warren Buffet. HBM Bioventures is blessed with a wizard CEO, Dr. Andreas Wicki, who is here today.

AARDEX Ltd, based in Zug, Switzerland, is of course my main focus. This

firm succeeded and eventually acquired APREX Corporation, which I had co-founded with Ray williams back in 1985. I ran APREX for several years until we needed venture financing, and our investors decided that the firm needed what they called professional management. That they got, but a succession of two professional managers managed to bankrupt the firm in 1995, at which point, Dr Jean-Michel Metry and 1 co-founded AARDEX Ltd in Zug. Under Jean-Michel's dynamic leadership, AARDEX has prospered, and eventually purchased the remants of APREX, so that all the intellectual property in compliance monitoring is in one place. Jean-Michel and our partner in this activity, Pierre-Alain Gaillard are both here today.

So my departure from Masastricht University is the end of several beginnings, which I expect to continue to pursue as stamina and health permit.

Thank you. 
18 


\section{REFERENCES}

1. Urquhart J. 14th Bowditch Lecture of the American Plyysiological Sociery. Blood-borne signals - the measuring and modelling of humord communication and control. The Physiologist 13(1):7-41, 1970 .

2. Concato J, Horwitz RI, Feinstein AR, Elmore JG. Schiff SF Problems of comorbidity in mortality after prostatectomy. JAMA 267: 1077-82, 1992.

3. Petri $\mathrm{H}_{3}$ de Ver HCW, Naus J, Urquhart. J. Prescription sequence analysis: a new and fast method for assessing certain adverse reactions of prescription drugs in large populations. Stat Med 7: $1171-75,1988$

4. Petri, H. The Prescription Drug History in Pharmacoepidemiology. Ph.D. Thesis in Epidemiology, Rijksuniversiteit Limburg, 1992.

5. Bergman RN. Toward physiological understanding of glucose tolerance: the minimal model approach. Lilly Award Lecture. Diabetes 38: $1512-1527,1989$.

6. de Klerk, E. Patient Compliance in Rheumatology - Experiences with an Electronic Monitoring Device. Ph.D. Thesis in Rheumatology, Maastricht University, 2002.

7. Urquhart J. ADR crisis management - before and after. SCRIP 1388: 19-21, Feb 22, 1989. (edi torial)
8. Petri $\mathrm{H}$, Urquhart J, Herings $\mathbb{R}$, Bakker A Characteristics of patents prescribed three different inhalational beta-2 agonists: an example of the channeling phenomenon. Post Marketing Surveillance $5: 45-53,1991$.

9. Leufkens HG, Urquhart J, Sricker BHC, Bakker A, Peri H. Channeling of controlled release formulation of ketoprofen (Oscorel) in patents with history of gastrointestinal problems. J Epidemiol Comm Health 46: 428 32, 1992 .

10. Cross I, Lee $H$, Westelinck A. Nelson J, Grudzinskas C, Peck C. Postmanketing drug dosage changes of 499 FDA-approved new molecular entities, 1980-1999. Pharmacoeptdemiol Drug Safety 11: 439-46, 2002

11. Heerdink ER, Urquhart J, Leufkens $\mathrm{HG}$. Changes in prescribed drug dose alter matket introduction. Pharmacoepidemiol Drug Safety $11: 447-453,2002$

12. Struijker-Boudier HAJ. A drug is not a drug is not a drug: a commentary. Pharnacoepidemiol Drug Safety 11:437-8, 2002. 
20 